ing seriously, or no longer able to make their wishes known. Arguably, most of these decisions, and the 22,500 related to pain relief, would not have been very different had they been made in a British hospital or general practice. They might have been different in a British hospice: the vast majority of all patients whose lives were ended had cancer. The practical issues raised by this suggest the need for a more collaborative and less polarised discussion of these issues than is currently being conducted in Britain.

The investigation found that 62 per cent of Dutch doctors had performed euthanasia at some time, but also that two-thirds of requests were not acceded to. Patients whose lives were ended were more often in their $60 \mathrm{~s}$ than over 80 . This does not suggest the frail elderly being pressurised by overenthusiastic doctors, or support slippery slope arguments generally. A good defence against the latter, indeed, is the kind of willingness shown by Dutch doctors to have their decisions (including their failure to report many of them properly) scrutinised in the way this book reports. But in the end, no safeguards, under any legal system, can substitute for the integrity of those taking these decisions. The real issues in the euthanasia debate are those which have to be tackled in the arena of medical education in ethics, communication and the relief of pain and suffering.

KENNETH M BOYD Scottish Director and Research Director,

Institute of Medical Ethics, 1 Doune Terrace, Edinburgh EH3 6DY

\section{Ethics, reproduction and genetic control}

Edited by Ruth F Chadwick, London, Routledge, revised edition, 1992, 200 pages, $£ 10.99$.

Published by Croom Helm Ltd in 1987, and in paperback form by
Routledge in 1990, this book has already been reviewed in the journal (by A J Burfoot, the June issue 1991, page 105). Since the first edition there have been many changes in reproductive technology and medical genetics. Therefore readers might expect the new edition to examine those developments in the context of Ruth Chadwick's field, social ethics. They will be disappointed. This edition has the same ten chapters, each unrevised and with references no later than 1986. There is a revised preface by $\mathrm{Dr}$ Chadwick of 14 pages (with 51 references up to 1992), but that is too short to update in vitro fertilisation, women's interests, egg donation, developments in genetics and gene therapy, all of which are fields which have undergone marked change.

Which changes should have been discussed? Surely the implementation of the Human Fertilisation and Embryo Act, with the regular visiting of IVF centres by HFEA sub-committees; or the role for independent counsellors, which is enshrined in the HFEA legislation. In IVF itself, technological advances (including sub-zonal injection methods) have led to successful pregnancies even in couples who were previously considered to be untreatable. Research into folic acid therapy for the fragile $\mathrm{X}$ syndrome has now run for over a decade - Jerome Lejeune's emotive paper needs updating; the reader should be told that folate has no effect on IQ but significantly improves behaviour. What has happened in Singapore? The government's eugenic programme, laid out in Chan's paper, was so stark and frightening that eight years on, we deserve a follow-up.

A further difficulty is that the essays on which this book is based were chosen provocatively, and are by authors who, individually, or as a group, do not reflect a balance of viewpoints, or even completeness in one particular country. For example, the chapters on 'Marriage and the family' (by the Board of Social Responsibility of the General Synod of the Church of England), on 'IVF and the law' (by Sir David Napley), on 'In vitro fertilisation and the Warnock Report' (by Professor R M
Hare), and much of the two chapters by Chadwick herself, 'Having children' and 'The perfect baby', deal with the UK experience. Where though is the UK clinical geneticist or reproductive clinician/scientist? Internationally renowned units are not far distant from Dr Chadwick's own base.

To a medical geneticist even the title is disturbing. 'Genetic control' is not what we seek to do when we see troubled couples or families in the genetic clinic. Geneticists hope to relieve distress (in most instances) by providing accurate, up-to-date and relevant information, as well as by listing the available options. When individuals are empowered to exercise their right to choose for themselves, the result is not eugenic but the reverse. This is because such personal choices will increase variation in the gene pool - a point not understood by Dr Chadwick (in her chapter 'The perfect baby') or by Amitai Etzioni or Germaine Greer, both of whom are cited. The unreferenced chapter by Robert Sinsheimer, 'The prospect of designed genetic change', begins with a confused description of gene therapy for diabetes which implies wrongly that transduction of beta cells in the Islets of Langerhans with an exogenous pro-insulin gene would also influence the germ cells. Sinsheimer ends like Hamlet with unclear ramblings so divorced from medical genetics and informed choice that I know not whether to believe him and shudder or to assume untruthful sarcasm. Those who wish to learn about gene therapy should skip Sinsheimer and read French Anderson (chapter 8) instead.

Those comments aside this book is an attempt to redress the balance between the technology and the social science. The missing link in that pursuit is a lack of the genetic counselling perspective. There are medical genetic teams that acknowledge the value of social scientists. In a proper second edition of Chadwick's book space might be found to reciprocate.

SANDY RAEBURN Professor of Clinical Genetics, Nottingham 